\title{
Porównanie wybranych parametrów biomechanicznych osób po upadku oraz osób, które nie uległy upadkowi
}

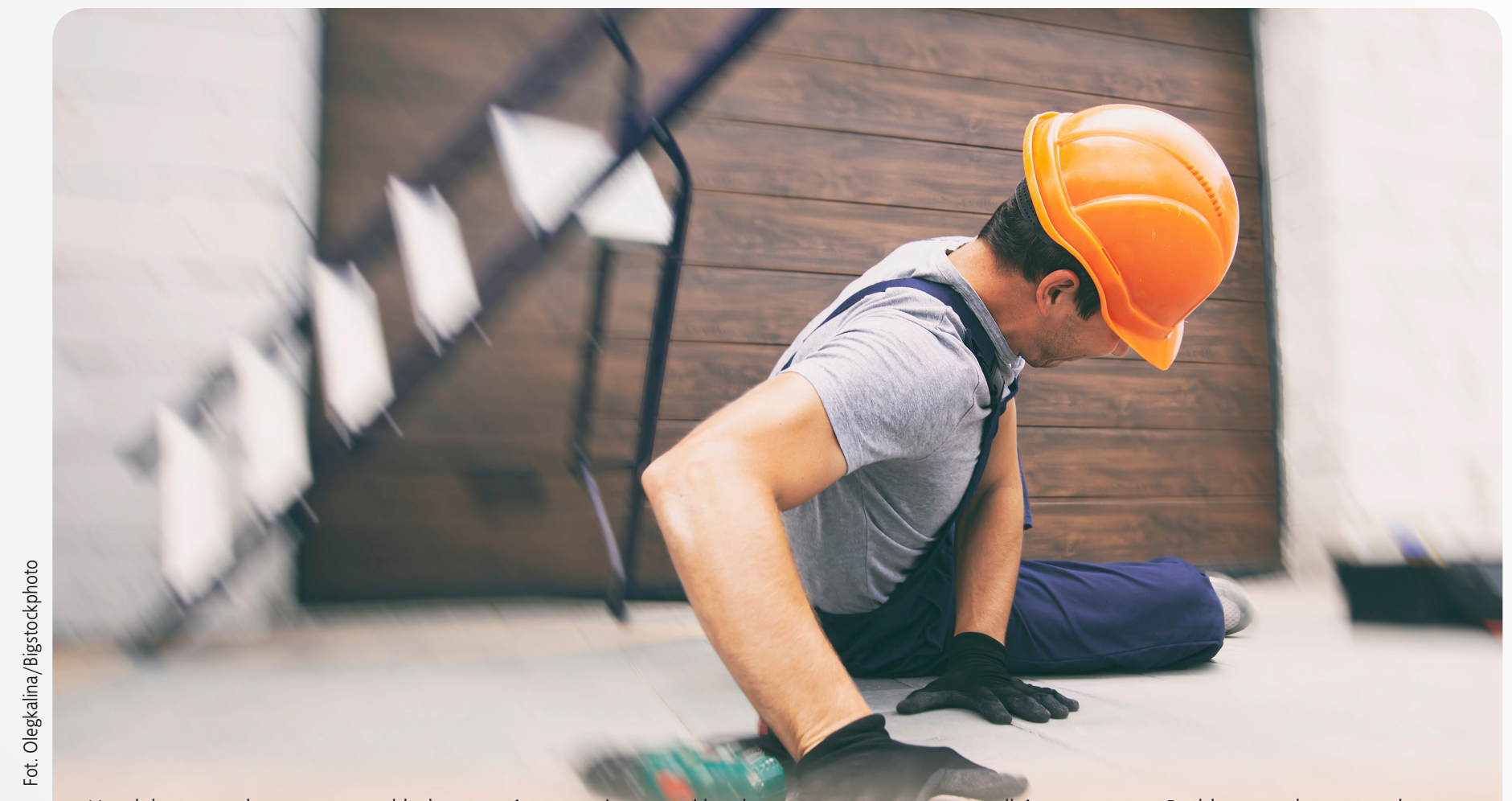

Upadek, spowodowany na przykład utratą równowagi, stanowi bardzo częstą przyczynę wypadków przy pracy. Problem ten dotyczy zwłaszcza pracowników starszych. Okazuje się, że każdego roku blisko 1/3 osób po 65. roku życia ulega upadkom. Narażone są m.in. osoby o pogorszonych parametrach fizycznych. Do tych niekorzystnych zmian dochodzi wraz z postępującym procesem starzenia, a także na skutek uszkodzeń układu ruchu. Wraz z wiekiem rośnie więc częstość upadków, a ich skutki dla zdrowia stają się coraz poważniejsze.

W artykule opisano badania nad osobami z grupy wiekowej 60-67 lat. Ich celem było: po pierwsze - porównanie wybranych parametrów biomechanicznych (tj. parametrów chodu, koordynacji wzrokowo-ruchowej, siły mięśniowej oraz zdolności utrzymywania równowagi) osób po upadku oraz osób, które nie uległy upadkowi, a po drugie - wskazanie tych parametrów, które mogą mieć wpływ na większą skłonność do upadku. Tymczasem różnice pomiędzy parametrami uzyskanymi dla obu badanych grup okazały się niewielkie i statystycznie nieistotne.

Słowa kluczowe: upadki, osoby starsze, siła, sterowanie, równowaga, możliwości fizyczne

\section{Comparison of selected biomechanical parameters of persons after a fall and persons who did not fall}

Falling out of balance is a very common cause of accidents at work. Older workers are particularly affected by this problem. It turns out that each year nearly $1 / 3$ of people over 65 experience a fall. Particularly vulnerable are, inter alia, people with impaired physical parameters. These unfavourable changes occur along with the progressive aging process and as a result of damage to the locomotor system. Thus, the frequency of falls increases with age, and the effects on health become more severe.

The article describes research on people in the 60-67 age group. Their aim was: firstly - to compare selected biomechanical parameters (i.e. parameters of walking, eye-hand coordination, muscle strength and the ability to maintain balance) of people after a fall and people who did not fall, and secondly - to indicate those parameters that may have an influence on a greater tendency to fall. Meanwhile, the differences between the parameters obtained for both studied groups turned out to be small and statistically insignificant.

Keywords: falls, elderly, strength, steering, balance, physical capabilities 


\section{Wstęp}

Z danych statystycznych dotyczących osób poszkodowanych w wypadkach przy pracy, na przykład w gospodarstwach indywidualnych w rolnictwie, wynika, że w latach 2019 i 2020 najczęstszą przyczyną tych wypadków były upadki i dotyczyły one prawie połowy osób poszkodowanych $[1,2]$. Ponadto, niezależnie od gałęzi przemysłu, czynnością, która zazwyczaj bezpośrednio poprzedzała wypadek było poruszanie się poszkodowanego - stanowiło ono 1/3 wszystkich czynności (36,7\% w 2019 r. i 36,2\% w 2020 r.). Istotnym zagrożeniem dla zdrowia pracowników, związanym z wykonywaniem pracy, jest możliwość utraty równowagi ciała podczas ruchu, w wyniku czego następuje upadek. Ma to szczególne znaczenie w przypadku pracowników starszych. Badania wskazują, że każdego roku ok. 1/3 osób w wieku powyżej 65 lat ulega upadkom [3]. Do ulegania upadkowi predysponowane są osoby, u których zaobserwowano ograniczenia możliwości utrzymania równowagi i mobilności [4] lub powolny chód [5]. Z badań wynika także, że u osób w wieku powyżej 60 lat występuje zmniejszenie wartości siły mięśniowej [5], a zwłaszcza siły kończyn dolnych i tułowia $[6,7]$, oraz spadek ruchomości w stawach skokowo-goleniowych [8], kolanowych i biodrowych [9]. Obserwuje się również mniejszą wydolność oddechowo-krążeniową [10], wynikającą ze zmniejszenia możliwości układu krążenia i oddechowego. Te zmiany wpływają na parametry chodu fizjologicznego [11] i dotyczą przede wszystkim prędkości chodu, długość kroku i czasu cyklu chodu [12]. Ponadto istnieje zależność pomiędzy wybranymi parametrami chodu i utrzymaniem równowagi a koordynacją wzrokowo-ruchową [13].

U starszych pracowników wraz z upływem czasu zmienia się wiele parametrów fizycznych. Konsekwencją zmian parametrów chodu lub spadku możliwości fizycznych są ograniczenia w wykonywaniu czynności pracy i w codziennym funkcjonowaniu. Te zmiany wynikają z procesu starzenia lub uszkodzenia układu ruchu na skutek wypadku i wywołanego nim urazu. Niestety, wraz z wiekiem rośnie częstość upadków, a ich skutki dla zdrowia stają się coraz poważniejsze.

Celem artykułu jest porównanie wybranych parametrów biomechanicznych osób po upadku z parametrami osób, które nie uległy upadkowi. Wykorzystano do tego wyniki badań, podczas których wybrano parametry biomechaniczne dotyczące chodu, koordynacji wzrokowo-ruchowej, siły mięśniowej i zdolności utrzymywania równowagi ciała oraz przeanalizowano je.

\section{Badane osoby}

Badania przeprowadzono na dwóch grupach po 30 osób: na grupie osób po upadku oraz na grupie obejmującej osoby, które nie uległy upadkowi. W grupie osób po upadku przyję to następujące kryterium: osoba po upadku

Tabela. Charakterystyka badanych grup osób

Table. Characteristics of the tested groups of people

\begin{tabular}{|c|c|c|c|c|}
\hline Parametr & Średnia & Min. & Maks. & $\begin{array}{l}\text { Odchylenie } \\
\text { standardowe }\end{array}$ \\
\hline \multicolumn{5}{|c|}{ OSOBY PO UPADKU } \\
\hline Wiek [lata] & 63,8 & 60,4 & 66,9 & 2,9 \\
\hline Wzrost $[\mathrm{cm}]$ & 174,3 & 170 & 180 & 4,6 \\
\hline Masa ciała [kg] & 77,0 & 60,5 & 80 & 5,6 \\
\hline $\mathrm{BM} I^{*}\left[\mathrm{~kg} / \mathrm{m}^{2}\right]$ & 24,3 & 20,5 & 26,3 & 2,6 \\
\hline \multicolumn{5}{|c|}{ OSOBY, KTÓRE NIE ULEGŁY UPADKOWI } \\
\hline Wiek [lata] & 64,1 & 60,2 & 67,3 & 2,8 \\
\hline Wzrost [cm] & 174,6 & 170 & 179 & 4,4 \\
\hline Masa ciała [kg] & 76,2 & 60 & 79,5 & 5,3 \\
\hline $\mathrm{BMI} *\left[\mathrm{~kg} / \mathrm{m}^{2}\right]$ & 24,0 & 20,0 & 26,4 & 2,3 \\
\hline
\end{tabular}

* Skrót od body mass index (wskaźnik masy ciała)

w ciągu ostatniego roku potknęła się i przewróciła, jednak nie doznała przy tym takiego urazu w obszarze układu mięśniowo-szkieletowego, który mógłby wpłynąć na wyniki pomiaru parametrów biomechanicznych. Badaniom poddano zdrowych, nietrenujących mężczyzn w wieku 60-67 lat o wzroście $170-180 \mathrm{~cm}$ i masie ciała $60-80$ kg. Badane osoby charakteryzowały się przeciętną ogólną kondycją fizyczną i psychiczną oraz nie przyjmowały na stałe leków mających wpływ na możliwości układu mięśniowo-szkieletowego lub zdolność utrzymania równowagi. Charakterystykę badanych grup przedstawiono w tabeli.

\section{Ocena parametrów chodu}

W celu oceny parametrów chodu zmierzono kąty w stawach kończyn dolnych - łącznie 12 wartości kątów w stawach biodrowym, kolanowym i skokowo-goleniowym lewej oraz prawej kończyny. Do pomiaru wartości kątów w stawach wykorzystano goniometry, które umieszczono tak, aby środek elementu ruchomego znajdował się jak najbliżej osi obrotu w stawie. Badania przeprowadzono podczas chodu w warunkach laboratoryjnych w pomieszczeniu, które umożliwiało przejście w linii prostej odległości $10 \mathrm{~m}$. Przejście po linii prostej powtórzono sześć razy, aby podczas badania można było zarejestrować 30 kroków.

Wartości wybranych kątów w stawach kończyn dolnych w płaszczyźnie strzałkowej, zarejestrowane podczas chodu, przedstawiono na wykresach (rys. 1.). Wyniki pomiarów wskazują, że zarówno w grupie osób po upadku, jak i w grupie osób, które mu nie uległy, średnia wartość kąta w stawie skokowo-goleniowym podczas chodu wynosi ok. 95\%, kolanowym - ok. $15^{\circ}$, a biodrowym - ok. $5^{\circ}$

\section{Ocena koordynacji wzrokowo-ruchowej}

Ocenę koordynacji przeprowadzono na podstawie pomiaru dokładności sterowania za pomocą pedału. Badanie polegało na kontrolowaniu siły wywieranej na pedał tak, aby na ekranie komputera krzyżyk odpowiadający wartości siły na pedale znajdował się we wskazanym miejscu prezentowanej krzywej wzorcowej.

Badania przeprowadzono na stanowisku do oceny dokładności sterowania, wyposażonym w pedał roboczy; badana osoba zajmowała pozycję siedzącą. Podczas badania dokładności sterowania kąty w stawach wynosiły: $0^{\circ} \mathrm{w}$ stawie ramiennym, $90^{\circ} \mathrm{W}$ stawie łokciowym, $105^{\circ}$ w stawie biodrowym, $105^{\circ} \mathrm{W}$ stawie kolanowym i $90^{\circ}$ w stawie skokowo-goleniowym. Kończyny górne były swobodnie ułożone na udach blisko stawów biodrowych.

Dokładność sterowania oceniana była według kryterium całkowego, opartego na kształcie charakterystyki zmierzonej podczas pomiaru siły na dźwigni w porównaniu z zadaną wartością [14]. Do badania dokładności sterowania losowo wygenerowano krzywą wzorcową, której przyporządkowywano zakres dobierany indywidu alnie dla każdej z badanych osób w zależności od maksymalnej wartości siły na pedale, wynoszący 2\% (dla minimum) i 20\% (dla maksimum) tej wartości. Wyniki badań dzielono przez wartość maksymalnego zakresu pomiarowego siły, aby móc je porównać

Wynikiem badania dokładności sterowania jest wartość błędu sterowania - im większy błąd, tym mniejsza dokładność

Wyniki pomiarów dokładności sterowania za pomocą pedału dla lewej i prawej kończyny dolnej przedstawiono na wykresach (rys. 2.) 
a)

\section{0}

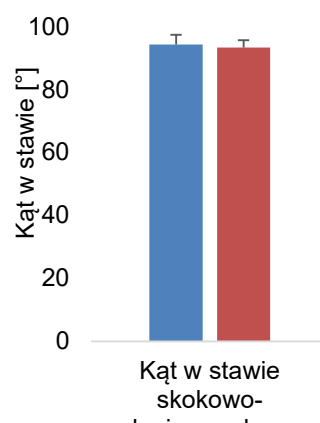

b) goleniowym lewym

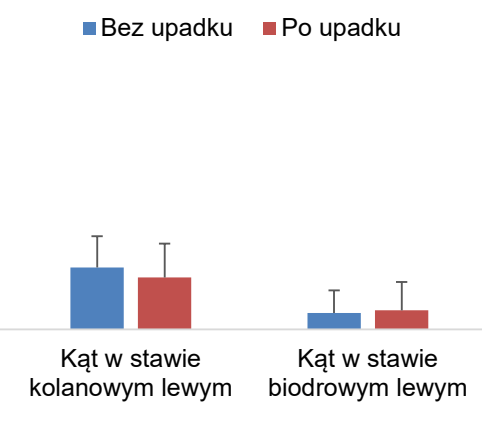

120

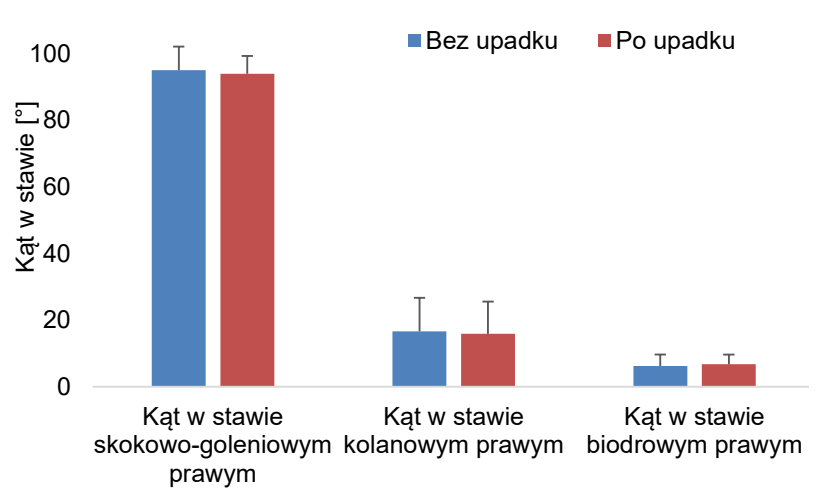

Rys. 1. Średnie wartości kątów w stawach kończyny dolnej lewej (a) i prawej (b) w płaszczyźnie strzałkowej podczas chodu

Fig. 1. Average values of angles in the joints of the left (a) and right (b) lower limb in the sagittal plane while walking

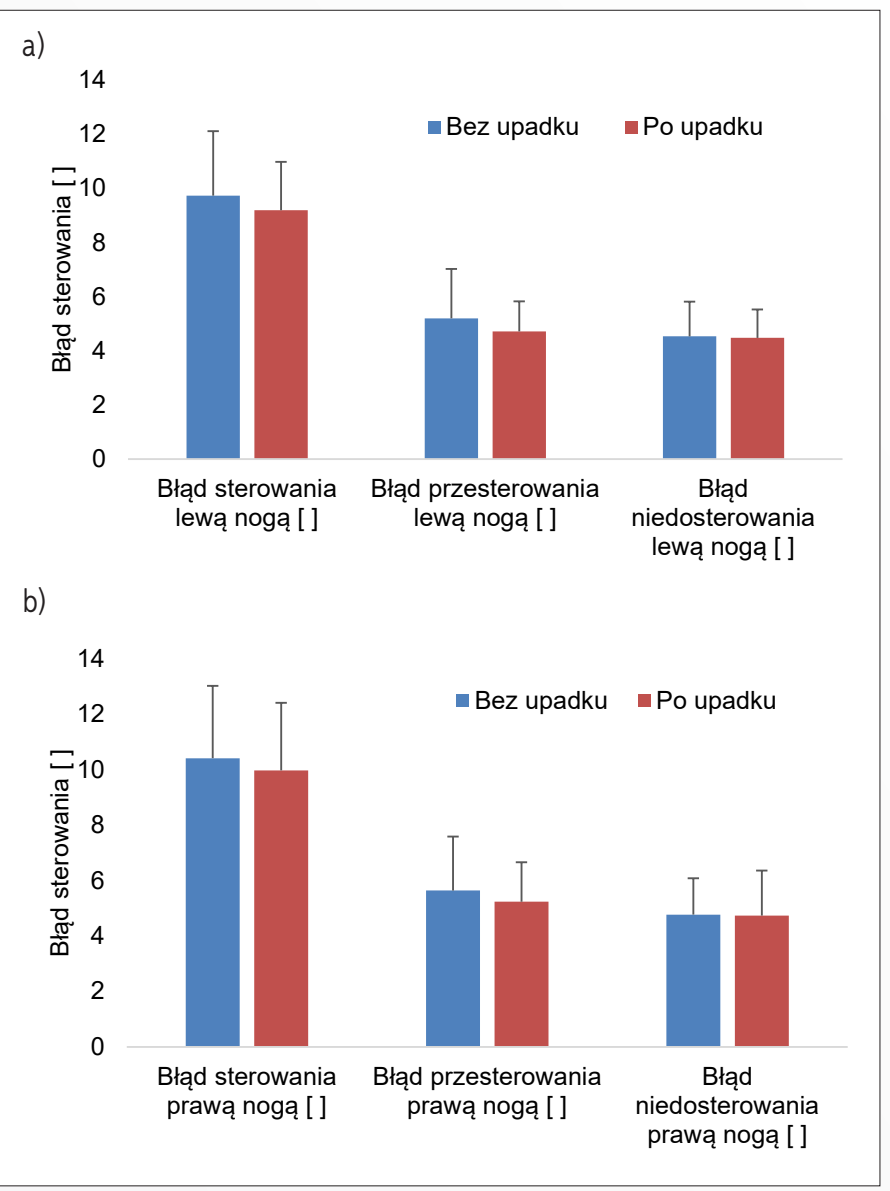

Rys. 2. Średnie wartości błędów sterowania - wynik oceny dokładności sterowania za pomocą pedału lewą (a) i prawą (b) kończyną dolną (większa wartość oznacza mniejszą dokładność)

Fig. 2. Average values of steering errors - the result of the assessment of the accuracy of control with the use of a pedal with the left (a) and right (b) lower limb (higher value means lower accuracy)
Różnice w dokładności sterowania pomiędzy grupą osób po upadku i grupą osób, które nie uległy upadkowi, są niewielkie i nieistotne statystycznie.

\section{Ocena siły mięśniowej kończyn dolnych}

Oceny siły mięśniowej kończyn dolnych dokonano w warunkach izometrycznych i izokinetycznych. Zmierzono wartości siły mięśni prostowników, zginaczy stawu kolanowego i skokowo-goleniowego lewej oraz prawej kończyny dolnej. Badania przeprowadzono z zastosowaniem zestawu do oceny i treningu siły. W warunkach izometrycznych zadaniem badanej osoby było użycie jak największej siły od siebie i do siebie na element pomiarowy urządzenia dźwignię zamocowaną do podudzia lub pedał zamocowany do stopy. Podobnie w warunkach izokinetycznych zadaniem badanej osoby było wywieranie siły, jednak w tym przypadku tę siłę wymuszał ruch wykonywany z prędkością $150 \%$, $120 \%$ s i $90 \%$ s. Zakres ruchu został wyznaczony przed rozpoczęciem pomiarów jako maksymalne zgięcie lub wyprost w badanym stawie. Oś obrotu momentomierza ustawiono w taki sposób, aby pokrywała się z osią obrotu w stawie kolanowym lub skokowo-goleniowym w zależności od badanej części ciała. Badania przeprowadzono w pozycji siedzącej. Podczas pomiaru siły mięśniowej prostowników kąty w stawach zostały ustawione zgodnie z procedurą badań zawartą w instrukcji urządzenia pomiarowego. Badana osoba została przypięta pasami na klatce piersiowej, biodrach i udach. Podudzie lub stopa zostały przypięte do dźwigni lub pedału urządzenia pomiarowego. Wynikami badań były maksymalne wartości momentów sił prostowników i zginaczy stawu kolanowego i skokowo-goleniowego lewej oraz prawej kończyny dolnej.

W badanych grupach osób nieznacznie większe wartości zginaczy podeszwowych i grzbietowych stawu skokowo-goleniowego uzyskano: w warunkach izometrycznych - dla prawej kończyny dolnej, a w warunkach izokinetycznych $\left(150^{\circ} / \mathrm{s}\right)$ - dla lewej kończyny dolnej.

Jednym z parametrów określających zależności w zakresie siły mięśniowej człowieka jest współczynnik agoniści/antagoniści, opisujący proporcje pomiędzy momentami sił mięśni prostowników i zginaczy w danym stawie. Wartość współczynnika agoniści/antagoniści w zakresie stawu skokowo-goleniowego różni się nieznacznie w przypadku pomiarów w warunkach izokinetycznych ( $150 \%$ s, rys. 3.). W grupie osób po upadku większe wartości uzyskano dla prawego, a mniejsze - dla lewego stawu skokowo-goleniowego.

Siła mięśni prostowników i zginaczy lewego stawu kolanowego w warunkach izometrycznych oraz w warunkach izokinetycznych $\left(120^{\circ} / \mathrm{s}\right)$ była zbliżona w obu badanych grupach. Siła mięśni prostowników i zginaczy prawego stawu kolanowego w warunkach izometrycznych oraz w warunkach izokinetycznych $(120 \%$ s) była nieznacznie większa w grupie osób po upadku. W badanych grupach nie zaobserwowano różnic w wartości współczynnika agoniści/antagoniści dla stawu kolanowego (rys. 4.) ani różnic w wartościach tego parametru pomiędzy lewą i prawą kończyną dolną.

\section{Ocena równowagi}

Jednym z celowanych testów oceny zdolności utrzymywania równowagi jest test $\mathrm{m}$ - CTSiB (ang. Modified Clinical Test of Sensory Interaction in Balance-zmodyfikowany test kliniczny interakcji sensorycznych w równowadze). Wykonuje się go w pozycji stojącej wyprostowanej: 


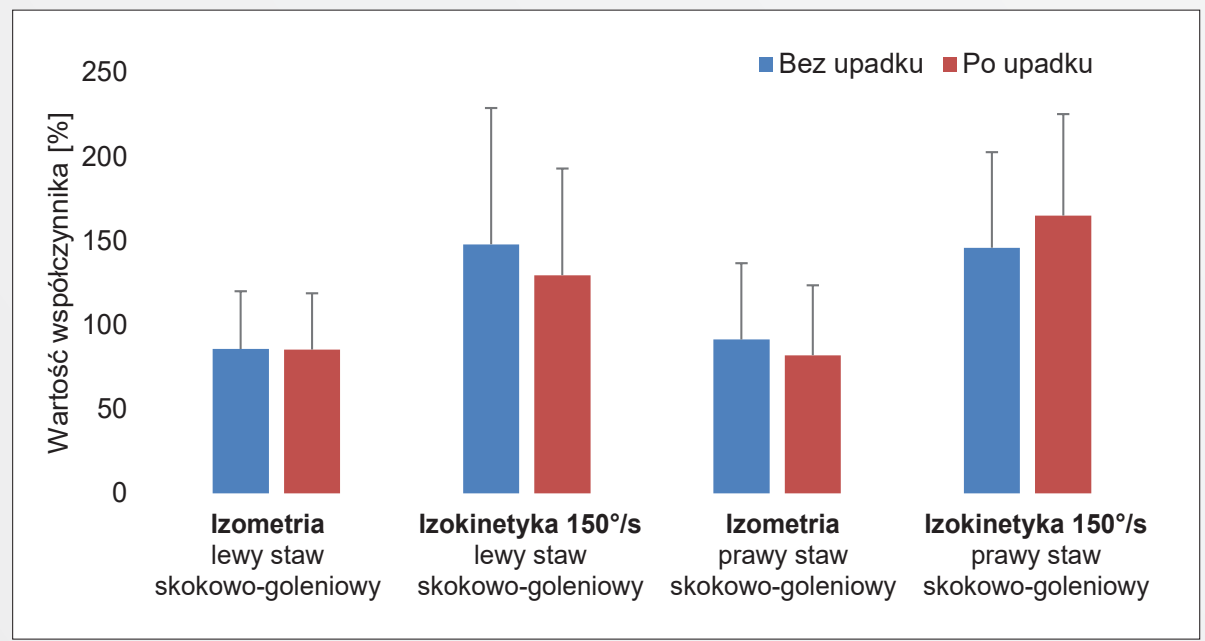

Rys. 3. Proporcje momentów sił mięśni zginaczy do prostowników (współczynnik agoniści/antagoniści) stawu skokowo-goleniowego lewej i prawej kończyny dolnej, zmierzone w warunkach izometrycznych i izokinetycznych przy prędkości $150^{\circ} / \mathrm{s}$

Fig. 3. Proportions of the moments of the flexor to the extensor muscles (agonist/antagonist ratio) of the ankle joint of the left and right lower limb, measured in isometric and isokinetic conditions at a speed of $150 \% \mathrm{~s}$

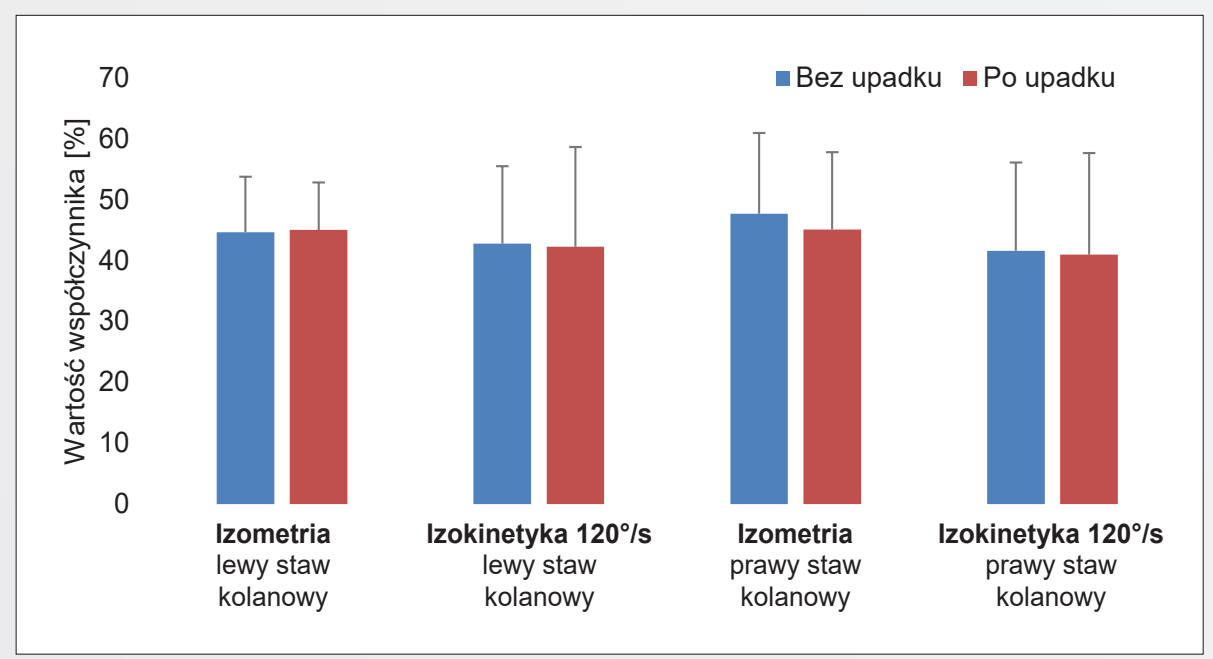

Rys. 4. Proporcje momentów sił mięśni zginaczy do prostowników (współczynnik agoniści/antagoniści) stawu kolanowego lewej i prawej kończyny dolnej, zmierzone w warunkach izometrycznych i izokinetycznych przy prędkości $120 \% \mathrm{~s}$

Fig. 4. Proportions of the moments of strength of the flexor to the extensor muscles (agonist/antagonist ratio) of the knee joint of the left and right lower limb, measured in isometric and isokinetic conditions at a speed of $120 \% \mathrm{~s}$

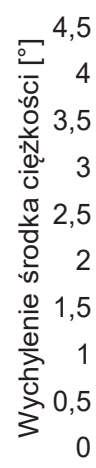

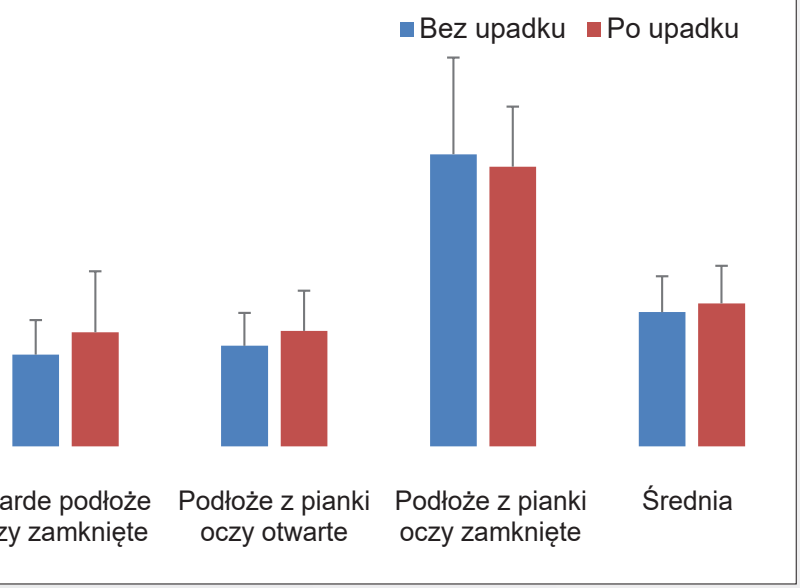

Rys. 5. Średni kąt wychylenia środka ciężkości podczas stania w pozycji wyprostowanej - wynik oceny zdolności utrzymywania równowagi za pomocą testu mCTSiB (większa wartość wychylenia oznacza mniejszą zdolność)

Fig. 5. The mean angle of deflection of the centre of gravity while standing in an upright position - the result of the assessment of the ability to maintain balance using the MCTSiB test (greater deflection value means lower ability)

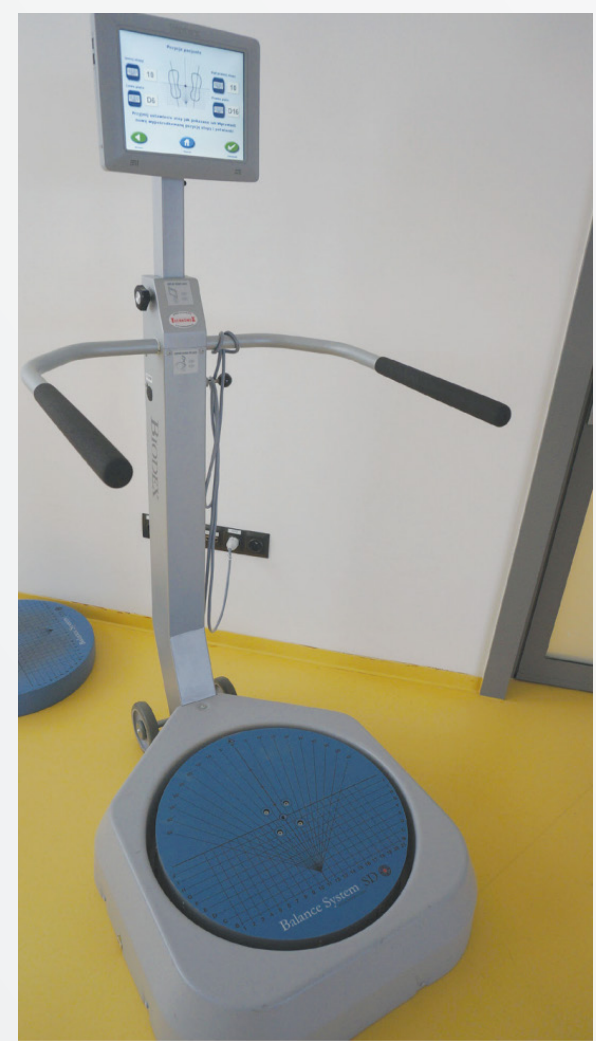

Fot. Platforma balansowa do oceny zdolności utrzymywania równowagi

Photo. Balance platform for assessing the ability to maintain balance

- na twardym podłożu z oczami otwartymi

- na twardym podłożu z oczami zamkniętymi

- na podłożu z pianki z oczami otwartymi

- na podłożu z pianki z oczami zamkniętymi.

Zgodnie z procedurą testu m-CTSiB badana osoba miała za zadanie utrzymywać nieruchomą pozycję stojącą wyprostowaną, z ramionami ułożonymi wzdłuż tułowia. Czas każdej próby wynosił 30 s, a pomiędzy kolejnymi próbami następowała przerwa trwająca 10 s. Pozycja stóp na podłożu była wyznaczana z zastosowaniem wskaźników określonych w procedurze przeprowadzania testu mCTSiB. Badania wykonano na platformie balansowej (zob. fot.).

Wynikiem testu jest pięć wartości liczbowych, określających wychylenia środka ciężkości od osi pionowej, wyrażone w wartościach bezwzględnych - stopniach. Wynik testu oceny równowagi mCTSiB na podłożu twardym i podłożu z pianki, z oczami otwartymi i zamkniętymi przedstawiono na rys. 5.

W obu badanych grupach osób zamknięcie oczu oraz dodanie utrudnienia w postaci podłoża z pianki spowodowało uzyskanie większych wartości kąta wychylenia środka ciężkości ciała podczas stania. Jednak podobnie jak w przypadku oceny pozostałych parametrów biomechanicznych nie można jednoznacznie wskazać parametru różnicującego badane grupy i wykazać jego wpływu na możliwość upadku podczas chodzenia. 


\section{Podsumowanie}

Celem badań było porównanie wybranych parametrów biomechanicznych osób po upadku oraz osób, które nie uległy upadkowi. Statystycznej analizie wyników badań poddano łącznie 70 parametrów biomechanicznych - przykładowe wy niki przedstawiono w tym artykule. Dotyczyły one chodu (12 parametrów, wybrane kąty w stawach kończyn dolnych), koordynacji wzrokowo-rucho wej (6 parametrów, wartości błędów podczas sterowania pedałem), siły mięśniowej (48 parame trów, wartości siły w warunkach izometrycznych i izokinetycznych) czy zdolności utrzymywania równowagi (4 parametry, na różnym podłożu z oczami otwartymi lub zamkniętymi). Analiza uzyskanych danych wskazuje na niewielkie, statystycznie nieistotne różnice pomiędzy parametrami uzyskanymi przez osoby po upadku i osoby, które nie uległy upadkowi. To oznacza, że spośród badanych parametrów biomechanicznych nie można jednoznacznie wskazać tych, które wpływałyby na możliwość upadku podczas chodzenia w badanej grupie osób w wieku 60-67 lat. Pomimo celowego doboru grupy osób do badań w zakresie oceny wybranych parametrów biomechanicznych wartości tych parametrów nie różnicowały osób po upadku i osób, które nie uległy upadkowi.

Skoro w badanej grupie osób w wieku 60-67 lat nie występują różnice dotyczące poszczególnych parametrów biomechanicznych związanych z funkcjonowaniem układu mięśniowo-szkieleto wego lub innych parametrów, które bezpośrednio lub pośrednio mogą wpływać na funkcjonowanie tego układu, to można przypuszczać, że główną przyczyną upadków w badanej grupie osób są jednak przyczyny losowe.

\section{Ograniczenia}

Badania przeprowadzono na wybranej grupie osób oraz z zastosowaniem wybranych metod pomiarowych w ściśle określonym zakresie. Mimo że osoby z badanej grupy uległy upadkowi, to jednak w tym przedziale wiekowym nie wynika to ze zmian analizowanych parametrów - taki wniosek jest uprawniony, biorąc pod uwagę liczbę przebadanych osób oraz ich wiek.

\section{BIBLIOGRAFIA}

[1] GUS. Wypadki przy pracy w 2019 r. - dane wstępne [31.03.2020]. https://stat.gov.pl/ob szary-tematyczne/rynek-pracy/warunki-pracywypadki-przy-pracy/wypadki-przy-pracy-w-2019roku-dane-wstepne,3,38.html.

[2] GUS. Wypadki przy pracy w okresie styczeń wrzesień 2020 r. - dane wstępne [10.12.2020] https://stat.gov.pl/obszary-tematyczne/rynek-pracy/warunki-pracy-wypadki-przy-pracy/ wypadki-przy-pracy-w-okresie-styczenwrzesien2020-r-dane-wstepne,3,41.html.
[3] TINETTI, M.E., SPEECHLEY, M., GINTER, S.F. Risk factors for falls among elderly persons living in the community. New England Journal of Medicine. 1988, 319: 1701-1707.

[4] RUBENSTEIN, L.Z. Falls in older people: epidemiology, risk factors and strategies for prevention. Age and Ageing. 2006, 35-S2: ii37-ii41.

[5] HONEYCUTT, P.H., RAMSEY, P. Factors Contributing to falls in elderly men living in the community. Geriatric Nursing. 2002, 5(23): 250-257.

[6] SCARBOROUGH, D., KREBS, D.E., HARRIS, B.A. Quadriceps muscle strength and dynamic stability in elderly persons. Gait \& Posture. 1999 10(1): 10-20.

[7] KAMIŃSKA, J., TOKARSKI, T., ROMAN-LIU, D. Adaptacja stanowisk pracy do możliwości siłowych i sprawnościowych pracowników starszych. CIOP-PIB, 2007.

[8] KERRIGAN, D.C., et al. Reduced hip extension during walking: healthy elderly and fallers versus young adults. Archives of Physical Medicine and Rehabilitation. 2001, 82: 26-30

[9] KERRIGAN, D.C., et al. Biomechanical gait alterations independent of speed in the healthy elderly: evidence for specific limiting impairments. Archives of Physical Medicine and Rehabilitation. 1998, 79: 317-322

[10] MELZER, K., et al. Comparison of equations for estimating resting metabolic rate in healthy subjects over 70 years of age. Clinical Nutrition. 2007, 26(4): 498-505.

[11] LEVINE, D., RICHARDS, J., WHITTLE, M. Analiza chodu. Urban \& Partner, 2014.

[12] MARCINIAK, T., WISZOMIRSKA, I., KACZMARCZYK, K., KOZDROŃ, E. Analiza parametrów czasowo-przestrzennych chodu osób starszych w aspekcie treningu. Postępy Rehabilitacji. 2011, 2: $19-26$

[13] CHIU, S.L., CHOU, L.S. Variability in inter-joint coordination during walking of elderly adults and its association with clinical balance measures. Clinical Biomechanics. 2013, 28(4): 454-458

[14] SŁOWIKOWSKI, J., DŹWIAREK, M., KONARSKA, M. Synergy Between Visual and Auditory Signals and Its Influence on the Follow-Up Regulation Quality. JOSE. 2006, 12(4): 369-377.

Opracowano na podstawie wyników IV etapu pro gramu wieloletniego "Poprawa bezpieczeństwa i warunków pracy", sfinansowanego w latach 2017-2019 w zakresie badań naukowych i prac rozwojowych ze środków Ministerstwa Nauki i Szkolnictwa Wyższego/Narodowego Centrum Badań i Rozwoju, wydano w ramach V etapu ww. programu wieloletniego, finansowanego w latach 2021-2022 w zakresie zadań służb państwowych przez ministra właściwego ds. pracy.

Koordynator programu: Centralny Instytut Ochro ny Pracy - Państwowy Instytut Badawczy.

\section{POLECAMY}

\author{
BROSZURĘ:
}

\section{ZESTAW ĆWICZEŃ POPRAWIAJACYCH ZDOLNOŚĆ UTRZYMANIA RÓWNOWAGI}

- Zdolność utrzymywania równowagi a parametry fizyczne.

- Metody oceny równowagi ciała.

- Ćwiczenia:

- na stepperze,

- rozgrzewająco-

-rozciagające,

- balansowe statyczne

i dynamiczne,

- balansowe z poduszką sensomotoryczną.

Autorzy:

dr Tomasz Tokarski

dr Joanna Mazur-Różycka

mgr inż. Patrycja Łach

mgr Patrycja Myszka

Wydawca:

Centralny Instytut Ochrony

Pracy - Państwowy Instytut

Badawczy

Broszurę można pobrać:

https://www.ciop.pl/CIOPPortal

WAR/file/89417/Tomasz-Tokarski -broszura-I-N-12.pdf 